the University of Edinburgh, previously held by Black. To him we owe the discovery of the maximum density of water. The centenary of John Dalton falls on July 27 of this year, but any commemoration must inevitably be clouded over by the results of the air raid of December 24, 1940, when the premises of the Manchester Literary and Philosophical Society were completely destroyed. From 1817 until 1844 Dalton was president of the Society, and within its walls he taught, lectured and experimented. The Society had an unequalled collection of his apparatus, but after digging among the ruins the only things found were his gold watch, a spark eudiometer and some charred remains of letters and note-books. A month after Dalton passed away in Manchester, Francis Baily died in London, after a life devoted to astronomy and kindred subjects. "Few men have left behind them so enviable a reputation. $\mathrm{He}$ was gentle as well as just; he loved and sought truth; he inspired in an equal degree respect and affection."

As is usual in these annual reviews of the centenaries of men of science, names of notable men born a century ago crowd closely upon one another, but it will perhaps be agreed that all those mentioned below have claims to recognition. Among the ranks of the physicists born in 1844 were Sir William F. Barrett (died 1925), who for more than thirty years held a chair in the Royal College of Science, Dublin; Sir William Abney (died 1921), who did much to put photography upon a scientific basis; and Ludwig Boltzmann (died 1906), professor of mathematical physics in the University of Vienna. Boltzmann died a tragic death, and his successor, F. Hasenöhrl, was killed in action on the Italian front in 1915. The chemists born in 1844 include Prof. J. Emerson Reynolds (died 1920), who occupied for twenty-eight years the chair of chemistry in the University of Dublin, and Ferdinand Hurter (died 1898), a native of Schaffhausen, Switzerland, who came to England in 1867 and became principal chemist to the United Alkali Company. Among astronomers, Prof. W. R. Brooks (died 1921) of the United States was famous as a 'comet hunter'. Charles Trépied (died 1907) was for many years director of the Observatory at Bouzariah, eleven kilometres from Algiers, while Annibale Ricco (died 1919), though he began life as an engineer, for nineteen years directed the observatory of Catania and Etna, his special subject being solar physics. In another sphere of scientific activity, Henry Alleyue Nicholson (died 1899) held professorships at St. Andrews and Aberdeen, and was Lyell medallist in 1888, while Auguste Michel-Lévy (died 1911) was director of the Geological Survey of France. A notice of the life and work of Michel-Lévy was read at a sitting of the Paris Academy of Sciences on December 21, 1914, under the shadow of war. The opening sentences ran, "Aux heures les plus graves de notre histoire nationale, l'Académie des Sciences a toujours tenu a proclamer bien haut sa foi inébranlable dans les destinees de la Patrie en n'interrompant en rien l'ordre régulier de ses travaux. C'est pourquoi, alors que notre territoire est encore envahi par l'ennemi, l'un de vos Secrétaires perpétuels vient, comme de coutume, vous rappeler en cette séance annuelle le souvenir de l'un de nos confrères disparus."

\title{
O BITUARIES
}

Sir Edward Poulton, F.R.S.

Edward Bagnall Poulton, who died on November 20, was born on January 27, 1856. His school life was spent at Oakley House, Reading, until he was nearly seventeen, when he commenced work in the office of his father, who was an architect. His interest, however, was so obviously in science that he was allowed to work for a scholarship, attending Rolleston's lectures at Oxford. He obtained an open scholarship in science at Jesus College in 1873, and after a crowded three years took a first class in the honour school of natural science. Next year he was appointed demonstrator in zoology under Rolleston, whose virile personality greatly impressed him. But working as one of his staff under him was a very different thing from being one of his students, and Poulton could do little research. During the long vacation, however, he was inspired by Foster and Balfour's work on embryology to follow their methods, and as a result was given a class to teach in that subject. His income being inadequate, he studied for a University scholarship in geology under Prestwich, eventually obtaining the Burdett-Coutts Scholarship. Thus it came about that, having resigned his demonstratorship, his first research was conducted on a geological subject, and his first paper was published in 1880 on remains in quaternary sands at Reading.

Rolleston was succeeded by Moseley in 1881 and Poulton, by now lecturer at Keble and Jesus Colleges, found him as helpful as Rolleston had been difficult. Moseley suggested that he should investigate some Challenger material, and as a result of his studies three papers were published in 1883 on the tongues of several Australian animals, including Ornithorhynchus. An investigation of the structure of the hair of this primitive creature then followed, sections of the head of an immature specimen having been lent by Dr. W. K. Parker. This resulted in a discovery of fundamental importance, for Poulton announced in 1888 that Ornithorhynchus possesses true teeth which cut through the gums but are replaced by horny plates.

But although he was professionally occupied with morphology, Poulton's real interest was in living insects. Such entomological studies as he saw being conducted by Westwood at Oxford did not, however, appeal to him, for they were concerned mainly with systematics. Poulton had read Wallace's essays on natural selection in $\mathrm{I} 878$, and these aroused what he described as "a lifelong delight" in the subject of the coloration of animals, particularly of insects. Weismann's studies in the theory of descent, of which he read in 1883 a translation by his friend $R$. Meldola, contained an account of variation in the colour of a caterpillar according to its surroundings, which especially interested Poulton, as it recalled observations he had made in boyhood upon that very species.

$\mathrm{He}$ began to work at once on that subject, and, amidst his morphological work, produced during 1884-88 a succession of papers on the colours of larvæ and pupæ and on experiments to test the factors influencing them, and their survival value. These researches led to his election to the Royal Society in 1889 , and in 1890 his great work "The Colours of Animals" at once set him in the front 
rank of upholders of natural selection, and until recently held the field as a comprehensive guide to the meaning of all forms of coloration. He became known as an ardent champion of pure Darwinism, finding in it a satisfying explanation of countless phenomena of colour and habits which, he always emphasized, must be studied and explained together. He first read "The Origin of Species" in 1875 as an undergraduate, and throughout his life it was almost like a Bible to him. He explained, in two books, the principles on which it was based, to aid those who, perhaps, felt the masterpiece rather too much for them.

The extravagant claims of the early mutationists particularly distressed Poulton, and he fought against the idea which Sir Oliver Lodge neatly expressed at the British Association in 1913-that not only is it untrue to say 'Natura non fecit saltum' but that it is doubtful if she ever does anything else. Partly, perhaps, for this reason and partly because mathematics were as incomprehensible to him as to the master he served, he was never attracted by genetics, though heredity greatly interested him, and he took much interest in eugenics.

The death of Westwood left vacant the recently founded chair of Hope professor of zoology at Oxford, and Poulton was elected to it in 1893 : there could scarcely have been a greater change. Westwood had been mainly occupied in the prevalent mode of adding to knowledge by describing new species and classifying them. In this he won world renown, but he did not move with the times, and warned Poulton against the dangers of the new doctrine. It was an irony that the young man so warned became one of its most forceful exponents. One of the first applications of Darwinism to problems of field natural history was the theory of mimicry, propounded by Bates in 1862, which explained the deceptive, superficial resemblance of one species of butterfly to another better protected by unpleasant qualities against the attacks of predators. Mimicry became one of Poulton's chief subjects, and all that he and his friends did to make known the extent of the phenomena convinced him that no explanation covers all the facts so well as natural selection. Critics have not always troubled to understand thoroughly the problems involved in minicry, and it is a pity that the logical terms which Sidgwick devised for Poulton ("pseudaposematic" and "synaposematic") are not more generally used. If these types of coloration are due to selective preferences of predators, then up. holders of the theory must produce evidence, and Poulton continually urged naturalists to observe and experiment in the field. A large body of facts has thus been accumulated, but it is not unfair to say that Poulton was not statistically minded; and most of the records, while adding more and more instances of observed cases, are not satisfying to the inquirer into "How much better ?" or "How much more of ten ?"

It was one of Poulton's correspondents who first showed that, when a bird attacks a butterfly and releases it, the shape of the bill is recognizably imprinted upon the wing, and much work on this subject has been done which goes to show that birds are probably the selective agents which theory requires for the production of mimicry in butterflies. On the other hand, if vertebrates avoid certain species as relatively distasteful, it is possible that these are destroyed by insect predators, and this point was also urged by Poulton, and evidence shows that this is so.
The importance of the fact that 'edibility' is relative, and merely a function of abundance, is frequently overlooked by critics. This point was emphasized by Poulton. The value of mimicry closely depends upon geographical distribution, and studies made by Poulton and his associates have shown that in such remarkable polymorphic species as Papilio dardanus and Pseudacraea eurytus, the prevailing form of the mimetic species corresponds numerically with the species of model most abundant in the losality. Moreover, if the protective influence of a model is removed by its decline in numbers, or by the mimetic species occurring in localities from which models are absent, the mimic is uncontrolled by selection and the mimetic resemblance deteriorates.

A Darwinian may be expested to show interest in sexual selection, and Poulton's influence resulted in important discoveries of structures used to produce scent in courtship, and of habits displaying special colours before the female. The extraordinary behaviour of certain male flies (Empididee), closely studied by one of his assistants, was shown to constitute a complete evolutionary series in the development of an elaborate courtship.

All this involved immense labour in correspondence, but there was also the care of the great collections which grew embarrassingly, so that it became beyond his power to attend to every detail himself, and he was very insistent upon detail ; thus to anyone but Poulton himself there seemed to be considerable confusion. He paid particular attention to making a label tell the whole story of a specimen, so that Hope Department labels are recognized to be the most informative in any collection in the world. But his passion for making the title of a communication summarize all the contents often proves a trial to bibliographers.

After his retirement in 1933, Poulton's friends hoped that, freed from the care of the department which he had made renowned, Poulton would settle down to the production of his magnum opus, but this was not to be. He was unable to shake himself free from the toils of correspondence; his powers weakened, his memory began to fail, and kindly death took him peacefully while he was still happy and interested.

His distinctions were many. He served on the Council of the Royal Society during 1897-99 and 1908-10; was vice-president during 1909-10 and Darwin medallist in 1914. He presided over the Linnean Society during 1912-16 and was Linnean medallist in 1922. When the second International Entomological Congress met at Oxford in 1912, he was its president; in 1915 he gave the Romanes Lecture. He thrice presided over the Entomological Society, the last occasion being at the centenary meeting in 1933, at which it became a Royal Society. Several universities, at home or abroad, conferred honorary doctorates upon him, and he was an honorary member or correspondent of many learned societies.

Friendly, affectionate and uncompromisingly truthful, he was a great believer in intercourse and a habitual attendant at the British Association meetings, at which he presided in 1937 and with which he went to South Africa and Australia. He also visited North America, and everywhere established links of closest friendship. He married in 1881 Emily, daughter of George Palmer, formerly M.P. for Reading, who predeceased him. They had two sons and three daughters, of whom only Mrs. Maxwell Garnett 
survives him. There are thirteen grandchildren and three great-grandchildren to carry on his memory.

By the death of Sir Edward Poulton, natural history, as Darwin taught it, has lost a master. He will long be remembered for his life's work at Oxford; from it has flowed inspiration and help to naturalists seeking truth all over the world. They found him a never-failing counsellor and a generous friend whom they learnt to love.

G. D. Hale Carpenter.

\section{Mr. H. F. Witherby, M.B.E.}

The death of H. F. Witherby on December 11 leaves a gap in the students of British ornithology which will be di fificult to replace. He was the second surviving son of Henry Forbes Witherby of Burley, Hants, and was born on October 7, 1873. After leaving school he entered the old family publishing firm of Witherby and Co., and some years ago retired, but resumed work again after the outbreak of war.

Although a successful business man, the study of birds was Witherby's main interest in life, and for this purpose he made many trips abroad in search of birds. He was specially interested in Spanish ornithology, and contributed several papers on this subject to the Ibis. Early in his career Witherby became interested in migration, and with the object of studying this phenomena visited many well-known localities on the east coast, and in 1938 even venturing to Fair Isle.

In 1909 he started the 'British Birds' ringing scheme, which from a small beginning has grown to be of national importance and is now carried on from the British Museum under the auspices of the British Trust for Ornithology. In 1907 he founded British Birds magazine, and this soon brought him in touch with all those interested in the study of birds in these islands. With the help of others he published a "Handlist of British Birds" in 1912, and in 1912-24, with the assistance of other ornithologists, a "Practical Handbook of British Birds". When these volumes became out of print he published during 1938-41 a more ambitious work, the "Handbook of British Birds", in five volumes; this has rightly been described as the best book on the birds of any country. Witherby himself was responsible for the systematic work and general editorship.

He had a very fine collection of both British and European birds which he sold to the British Museum, giving the proceeds to the British Trust for Ornithology, a body he took great interest in from the beginning. His collection was very carefully made, mainly for the purpose of studying races and plumages. Together with the late Dr. C. B. Ticehurst he did much to elucidate the moults and sequence of plumage of our native birds-indeed it might be said of European species also. It was Witherby who cleared up the long-disputed question as to how the rook developed its bare face, and in an article in British Birds proved it was a matter of age, not wear. Witherby was a very careful and painstaking worker, and would take an enormous amount of trouble before admitting a new species to the British list, or a record of a rare visitor. The late Dr. Hartert may be said to have introduced the trinomial system into ornithology in Great Britain, and Witherby was one of the first to appreciate the importance of this step.

As editor of British Birds, Witherby occupied a unique position in the study of our native birds, and he will be sadly missed by his many friends and correspondents; to teginners he was especially helpful and encouraging. During 1924-27 he was chairman of the British Ornithologists' Club, and president of the British Ornithologists' Union durirg 1933-38. On his retirement he was awarded the Godman-Salvin Medal for his work on ornithology.

In 1904 he married Lilian, daughter of the Rev. S. Gillson, and leaves two sons and three daughters.

N. B. KinNEAR.

\section{NEWS and VIEWS}

\section{Secondary Education in Great Britain}

The valuable statement "The Open Door in Secondary Education", issued by the members of the Education Sub-Committee of Nuffield College Social Reconstruction Survey, does full justice to the twin aims of educational reform: maintenance of the quality of the education provided, while making sure that opportunities at present the privilege of a minority become the heritage of the nation. Its six recommendations are accompanied by a brief survey which indicates the rapidity with which opinion has advanced in this field. First, the Statement recommends that in all schools which receive any grants from the State or from local education authorities, tuition should be free and adequate maintenance grants should be given. Secondly, the scales on which grants are made to schools should vary according to the education they provide, especially in equipment, staiffing ratio and opportunities for advanced work. To desl with the allocation of grants and with the question of control involved in this second recom. mendation, establishment by the Board of Education of a school grants central committee on the lines of the University Grants Committee is proposed, assisted by a small number of regional committees.

All schools for children between the ages of eleven and eighteen should be inspected by the Board of Education at intervals of not more than five years. All private schools which have not yet been formally recognized should be required to obtain from the Board a certificate of efficiency : but no school should be closed by the Board of Education without the right of appeal to an independent tribunal. One member of the Committee, Sir Richard Livingstone, regards this proposal as too drastic and open to abuse, and would tackle the evil of the undesirable school by giving a certificate to schools which submit to voluntary inspection and are approved, or by refusing anyone leave to teach who does not hold a university degree or has not attended an approved course for training in teaching.

The Statement then recommends that the school grants committee and the local education authorities should be empowered to make grants to children to enable them to pass from schools under their jurisdiction to independent private schools if they secure places in them. Maximum grants should be fixed by the school grants committee. Finally, such grants should only be made to children entering schools which observe the following conditions to the satisfaction of the Board of Education: (a) that to the extent of their normal numbers they admit children 